\title{
ANALYSIS OF THE LEAVES OF ILEX CASSINE.
}

By F. P. Venable, Ph. D.

The Yopon (Ilex Cassine, Linn), is described in Hale's "Woods and Timbers of North Carolina," as an elegant shrub 10 to 15 feet high, but sometimes rising into a small tree 20 to 25 feet. It has, according to the same authority, for its habitat the strip of country from Virginia southward along the coast, never extending, however, very far into the interior. The leaves are $\frac{1}{2}$ to 1 inch long, with a smooth surface, and fine serrated edge. The plant is an evergreen, and its dark green leaves and bright red berries make it attractive as an ornamental shrub. In the region of the Disma] Swamp, and in other sections the leaves are annually gathered, dried, and used for tea. This decoction is, according to Hale, oppressively sudorific, at least to those unaccustomed to its use. The famous "Black Drink" of the southern Indians was made from the leaves of this shrub. "At a certain time of the year they come down in droves from a distance of some hundred miles, to the coast for the leaves of this tree. They make a fire on the ground and putting a great kettle of water on it, they throw in a large quantity of these leaves, and seating themselves around the fire, from a howl that holds about a pint, they begin drinking large draughts, which in a short time occasions them to vomit freely and easily. Thus they continue for the space of two or three days, until they have sufficiently cleansed themselves, and then every one taking a bundle of the leaves, they all retire to their habitations." Having on hand a small sample of these leaves proeured from New Berne during the Winter of 1883 , it seemed desirable to make an examination of them to decide, if possible, the presence of any alkaloid or other principle which would make the decoction useful as a beverage. The usual treatment with magnesium oxide, exhaustion with water, separation by means of chloroform and subsequent purification, was adhered to, resulting in obtaining a small amount of a white sub. stance slightly soluble in water, more so in alcohol, and easily soluble in chloroform, which gave distinctly the tests for caffeine, especially the murexide reaction, and very closely resembled a specimen of pure caffeine from Powers \& Weightman.

This caffeine formed .32\% of the dried leaves. Later on, in May, a much larger supply of the same leaves was gotten from the 
neighborhood of Wilmington. A more thorough examination of them was then made with the following results:

Water in air-dried sample.............13.18

Extracted by water................26.55

Tannin ....................... 7.39

Caffeine .......................... .27

Nitrogen (on combustion) . .......... $\quad .73$

Ash . . . . . . . . .

The analysis of the ash is shown in column I.
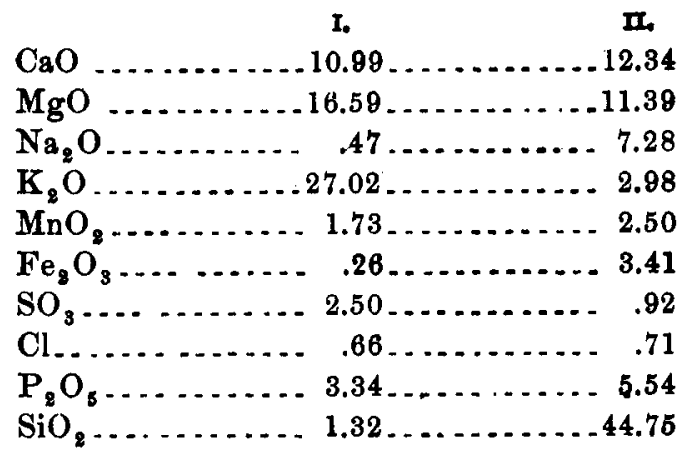

The Mate or Brazilian Holly (Tex Paraguayensis), belongs to the same genus. Its ash analysis, as made by Senor Arate, is given in column II. The plant grows wild in Brazil and is very largely used by the South Americans. It has, according to Peckolt (Pharm. J. Trans. [3] 14, 121-124. Abstract, Jour. Chem. Soc., 1884, 479), been planted, and seems to succeed well, in the Cape of Good Hope, Spain and Portugal. It is stated that six different species of Ilex are used in the preparation of this tea Peckolt gives, in his analysis of the air-dried leaves, the percentage of caffeine as .639. The average percentage of analyses, by different authors, is about 1.3. I can find mention of only one other Ilex used as a substitute for tea. The analysis of this by Ryland and Brown is quoted in Blythe's "Composition and Analysis of Foods," p. 343. It is called the Ilex Cassiva, is said to be used as a tea in Virginia, and the percentage of caffeine is given as.12. This is probably the same thing as the Yopon, the analysis of which is give above, and the "cassiva" may be a misprint for " cassine."

University of North Canolina. 